\title{
Frontières
}

\section{Sans rêve et sans abri}

\section{Raymonde Duchesne}

Volume 17, numéro 2, printemps 2005

Surtout, ne pas souffrir

URI : https://id.erudit.org/iderudit/1073498ar

DOI : https://doi.org/10.7202/1073498ar

Aller au sommaire du numéro

Éditeur(s)

Université du Québec à Montréal

ISSN

1180-3479 (imprimé)

1916-0976 (numérique)

Découvrir la revue

Citer ce document

Duchesne, R. (2005). Sans rêve et sans abri. Frontières, 17(2), 100-100.

https://doi.org/10.7202/1073498ar d'utilisation que vous pouvez consulter en ligne.

https://apropos.erudit.org/fr/usagers/politique-dutilisation/ 


\section{SANS RÊVE ET SANS ABRI}

Raymonde Duchesne, artiste*

un matin

le jour ne s'est plus levé une route sans trace un regard vers l'inconnu un pas vers le néant

d'une aurore fragile $d^{\prime}$ 'une noirceur sans fin d'un œil mouillé la peur de vivre de ces instants de givre de l'antenne de mon âme naît un sentier nouveau de là un souffle d'espoir

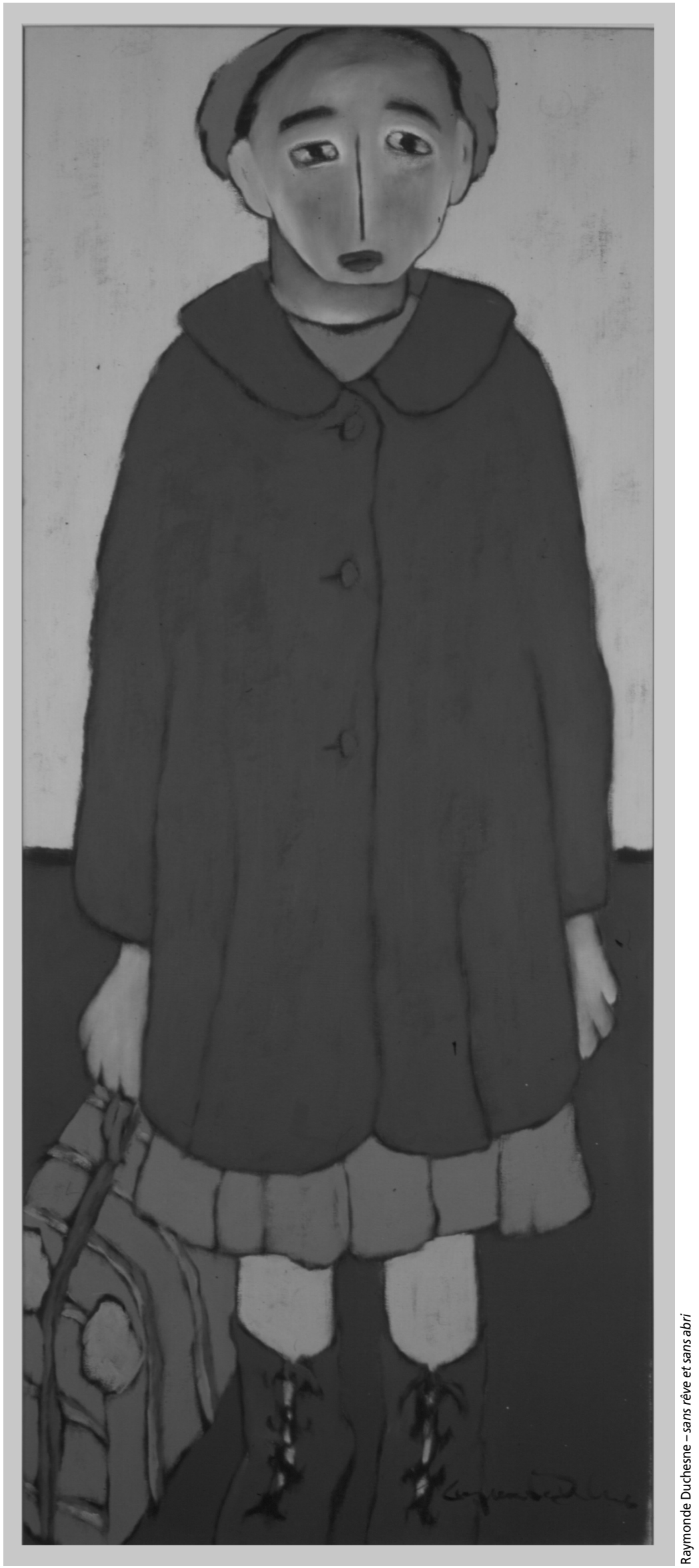

